\title{
The Impact and Challenges of Cloud Computing Adoption on Public Universities in Southwestern Nigeria
}

\author{
Oyeleye Christopher Akin ${ }^{1}$ \\ Department of Computer Science and Engineering, \\ Ladoke Akintola University of Technology, \\ Ogbomoso, Oyo State, Nigeria
}

\author{
Fagbola Temitayo Matthew ${ }^{2}$, Daramola Comfort $\mathrm{Y}^{3}$ \\ Department of Computer Science ${ }^{2,3}$, \\ Federal University, Oye-Ekiti ${ }^{2,3}$, \\ Ekiti State, Nigeria
}

\begin{abstract}
This study investigates the impact and challenges of the adoption of cloud computing by public universities in the Southwestern part of Nigeria. A sample size of 100 IT staff, 50 para-IT staff and 50 students were selected in each university using stratified sampling techniques with the aid of wellstructured questionnaires. Microsoft excel was used to capture the data while frequency and percentage distributions were used to analyze it. In all, 2, 000 copies of the questionnaire were administered to the ten (10) public universities in the southwestern part of Nigeria while 1742 copies were returned which represents a respondent rate of $87.1 \%$. The result of the findings revealed that the adoption of cloud computing has a significant impact on cost effectiveness, enhanced availability, low environmental impact, reduced IT complexities, mobility, scalability, increased operability and reduced investment in physical asset However, the major challenges confronting the adoption of cloud are data insecurity, regulatory compliance concerns, lock-in and privacy concerns. This paper concludes by recommending strategies to manage the identified challenges in the study area.
\end{abstract}

Keywords-cloud computing; cloud adoption; informationcommunication-technology; public-universities

\section{INTRODUCTION}

Information and Communication Technologies (ICT) are powerful enabling tools for educational change and reform introducing new methods of teaching and conducting research as well as provisioning of educational facilities for online learning, teaching and research collaboration. It thus represents a potentially equalizing strategy for developing countries. The great flexibility offered by ICT strongly facilitates the acquisition and use of available knowledge to expand access to education, strengthen the quality of education and improve the quality of the classroom teachinglearning processes via access to electronic active teaching and learning, research, training and development resources on the global collaborative network of internetworks and use of ICT tools in education. It can be said to be the bedrock for successful scientific research and development in education.

ICT is considered a critical tool in preparing and educating students with the required skills for the global workplace. It educates students so that they can continually adapt to a work world of continuous technological innovations [1]. The ability to become lifelong learners within a context of collaborative environment and the ability to work and learn from experts and peers in a connected global community are major flexibilities offered by ICT [2]. Iwasokun, Alese, Thompson and Aranuwa [3] stressed that ICT is a versatile tool for running a smooth and efficient university system, giving support in areas such as lecture delivery, private studies, information disseminations, program (conferences and seminars) planning and execution, communication at different levels, crisis prevention and management.

Unfortunately, the recurring Global Economic Meltdown (GEM) and national financial hiccups currently embattling the developing countries continue to pose a serious threat to the survival of quality education as governmental institutions and University administrators helplessly fight the provision of unlimited fundamental ICT facilities and support tools, services and applications needed to facilitate effective teaching and Sustainable Educational Research and Development (SERD) activities in Universities. Furthermore, developing countries generally face challenges in terms human and financial resources needed to harness the potential of ICT successfully and effectively in education [1].

As much as the adoption of ICT in education becomes imperative, cost of owning of the required ICT infrastructures, licensing, standards requirement, cost of maintenance, electrical power supply and physical security of these facilities come at a great financial expense. Gerald and Eduan [4] stressed that availability and accessibility to ICT infrastructures and services by staff and students in Universities in most developing economies are limited or nonexistent. Inadequate funding of universities by the government at all levels, erratic power supply, operational cost, high cost of equipment renewal, cost of maintenance and bandwidth, lack of maintenance practice and lack of ICT budget by the Universities are the major factors responsible for the failure of the survival of ICT in Universities.

Effective teaching-learning process, research and development activities have been hampered as a result of these menaces. For example, when power is rarely supplied, the admirable goals of transforming education with ICT and taking a paradigm shift in education is all a dream; having access to educational resources on demand, anytime, anyhow and anywhere is a story and e-learning would not be sustained either [5]. 
Sequel to these challenges, the adoption of cloud computing, a service-oriented alternative to ICT provisioning and deployment, with the potential to yield low cost, improved efficiency and availability become imperative in Universities. Mehmet and Serhat [6] identified some of the benefits offered by cloud computing in education to include on-demand access to online database repositories, e-learning platforms, digital archive, portals, research applications and tools, file storages, e-mails and other educational resources anywhere for faculty, administrators, staff, students and other users in university.

Therefore, in this paper, the impact and challenges of the adoption of cloud computing on public Universities in the Southwestern part of Nigeria is investigated. The impact assessment investigates the gains derived from the adoption of cloud computing in Nigerian Universities while the challenges assessment investigates the problems and constraining factors mitigating with the successful adoption and use of cloud computing in Nigerian Universities. It concludes by recommending strategies to manage the identified challenges in the study area.

Section II of this paper presents a literature review and conceptual underpinnings of cloud computing adoption in public Universities. The materials and method are presented in Section III. In Section IV, the results and interpretation are presented and discussed while the conclusion, recommendation and future research work are presented in Section V. Questionnaire for the evaluation of the impact and challenges of cloud computing adoption and use by Universities in Southwestern, Nigeria is provided at the appendix section after the references.

\section{LITERATURE REVIEW AND CONCEPTUAL UNDERPININGS}

The conceptual, logical and architectural development over Networking, Internet and Grid computing has given birth to the third $\left(3^{\text {rd }}\right)$ technological revolution after Personal Computer (PC) and the internet known as cloud computing [6]. Cloud computing can be described as a composite threetier delivery, development and application platform [7-8]. As a delivery platform, it uses an on-demand cloud-based infrastructure to deploy an infrastructure or applications, for example, the Amazon Elastic Cloud.

The on-demand cloud-based development environment provides a general purpose programming language (for example, Bungee Labs, Coghead, google sites) as a development platform. As an application platform, it is used to develop and deploy end-user applications (for example, Salesforce.com, NetSuite, Cisco-WebEx and google docs).

Olabiyisi et al. [9] defined cloud computing as an elastic and scalable utility model that offers flexible, ubiquitous, ondemand network access to a shared pool of configurable computing resources (for example, servers, data centers, networks, applications and services) that can be rapidly provided and released with limited interaction of service provider or the management. It provides shared infrastructure, self-service, dynamic and virtualized pay-per-use platforms which put it on high demand. Cloud computing implies a level of dynamic, flexible resource sharing and allocation of assets.
Edtech [10] conducted interview with a panel of the world's top technologists discussing new technologies changing higher education especially "education in the cloud" trend. Shel Waggener, the senior vice president of Internet2 and former Chief Information Officer (CIO) at University of California in Berkeley, Ted Dodds, Chief Information Officer and Vice President at Cornell University, Ron Kraemer, the vice president and $\mathrm{CIO}$ at Notre Dame University and Bill Wrobleski, Director of infrastructure services for information and technology services at University of Michigan discussed issues relative to benefits of cloud adoption, risk factors and risk management practices. A great number of advantages of using cloud computing in education were highlighted and techniques for mitigating the risk of cloud adoption were explained.

Gerald and Eduan [4] conducted a survey on the adoption of cloud computing among public universities and FET colleges within South Africa. The authors argued that public universities and colleges share many similar operational processes such as course offerings, admissions, enrollments, bursaries, research and graduations that can be standardized across the higher education sector and offered as a set of services through cloud to the many colleges and universities in a more cost effective way than is currently the case. The results of the analysis shed some light on the current state of cloud computing adoption within the South African public higher education sector, the main factors that fuel its adoption, the main barriers that impede its adoption and the direction it may take in future as it matures.

Abdulsalam and Fatima [5] argued that cloud computing is the solution to ICT in higher education in Nigeria. The authors identified scarcity of ICT infrastructure and lack of access, high cost of ownership, unsteady and inadequate electrical power supply as factors that are limiting the infusion of ICT in Nigeria higher education. They claimed that the prospect of a maturing cloud of on-demand infrastructure, application and support services is important as a possible means of driving down the capital and total costs of ICT in higher education, facilitating the transparent matching of IT demand, scaling ICT, fostering further ICT standardization and accelerating time to market by reducing ICT supply bottlenecks.

\section{MATERIALS AND METHOD}

The methodology and approach adopted in this paper are described below. In this section, the research questions are highlighted, the study area, sampled population and research techniques used are discussed.

\section{A. Research Questions}

To realize the purpose of this research study, three (3) research questions are formulated as follows:

- What is the level of adoption of cloud computing by Universities in the study area?

- What are the benefits associated with the adoption of cloud computing by Universities in the study area?

- What are the challenges and the constraining features to the successful adoption and use of cloud computing by Universities in the study area? 


\section{B. Data Source and Presentation}

This study is an empirical research which investigates the level of adoption, benefits and challenges of cloud computing on universities in southwestern part of Nigeria. The instrument for data collection was a well-structured questionnaire titled, "The Evaluation of the Impact and Challenges of Cloud Adoption and Use on Universities in Southwestern, Nigeria" with three (3) parts. The first part provides vital biodata information about each respondent while the second part provides information on the assessment of the adoption of cloud computing in universities. The third part assesses the impacts of cloud computing on Universities in south western part of Nigeria while the fourth part investigates the challenges of using cloud computing in the study area.

The questionnaire was validated and tested for reliability using the Pearson Product Moment Correlation.

Cronbach alpha reliability coefficient $(\alpha)$ of 0.89 was obtained, an indication that the instrument was reliable for data collection. In all, 2, 000 copies of the questionnaire were administered to the ten (10) public universities in the southwest geo-political zone of Nigeria while 1742 copies were returned which represents a respondent rate of $87.1 \%$.

A total of hundred (100) IT staff, fifty (50) para-IT staff and fifty (50) students were surveyed in each university. Microsoft Excel was used to capture and analyze the data obtained from the duly-filled copies of questionnaire while frequency, mean and percentage distributions were the descriptive techniques used. The descriptive survey was adopted to obtain the opinion of a representative sample of the target population so as to be able to infer the perception of the entire population.

\section{RESULTS AND INTERPRETATION}

The results of the research on the trends of adoption of cloud computing, the impacts and challenges associated with the adoption and use of cloud computing on Universities in Southwestern Nigeria are presented and discussed in this section.

\section{A. Trends of Adoption of Cloud Computing by Universities in Southwest Nigeria}

The analysis of the findings for research question 1 is presented in figures ( 1 and 2 ). The responses obtained from 1742 respondents in this research study indicated that out of the ten (10) universities in the study area, nine (9) universities have already adopted the technology and using it which represents $90 \%$ adoption rate. This confirms the report by Edudemic [11] that many higher education and research institutions have moved to the cloud for email and collaboration services. However, the primary reluctance of few other institutions to expand their use of cloud services has been based on concerns over privacy, security and the potential or perceived risks associated with intellectual contents.

As illustrated in figure 2, the responses obtained indicated that seven (7) universities use SaaS. Applications including google docs, Moodle, Google Mail, Yahoo Mail and NetSuite offered by SaaS in universities are universal, free and in high demand by the entire university community which accounted for its widest adoption and use. PaaS in universities including Google sites, online databases, Microsoft Dynamics CRM online and integrated development environment are only used by a limited number of consumers including the developers, researchers and other technical personnel that are for research, training and development purposes. Thus, in the result obtained, only two (2) universities use PaaS. IaaS in education offers oracle coherence, educationERP.net, microsoft, virtual computing laboratories, servers and operating systems and adopted by one (1) university for e-learning and portal hosting. This result corroborates the report of Marinela and Anca [12] that the highest number of cloud consumers subscribes to SaaS.

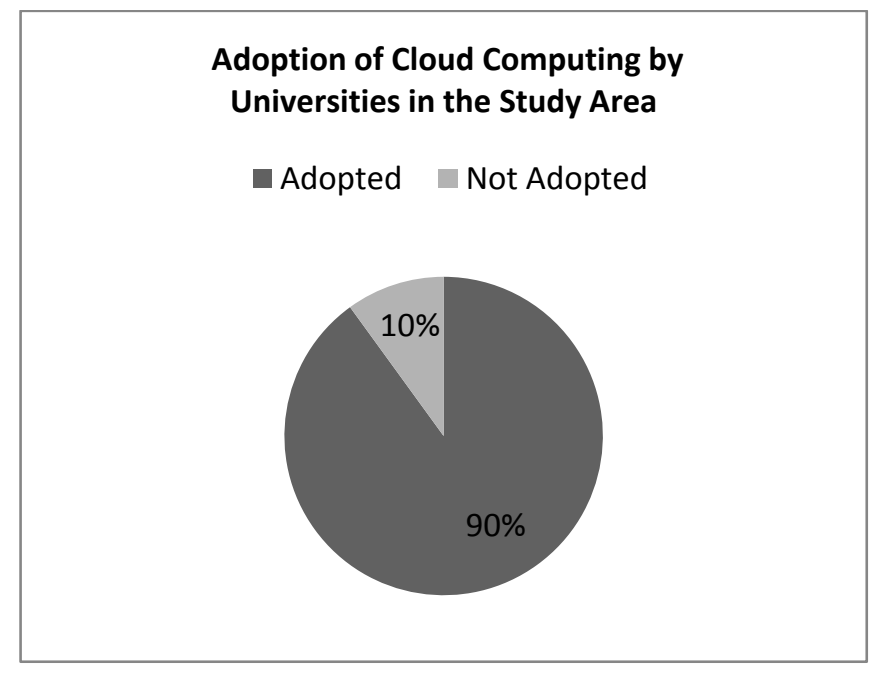

Fig. 1. Result of adoption of cloud computing

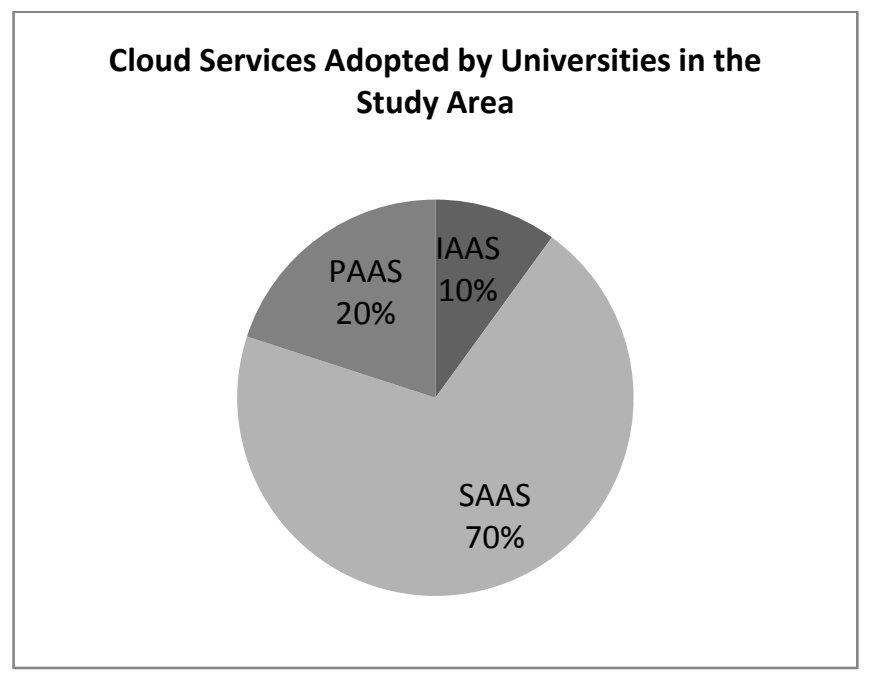

Fig. 2. Result of cloud services adopted in the study area.

The result of the findings obtained for research question 2 is presented in Table 1. The major benefits being derived by the use of cloud computing include cost efficiency which is the most important factor that drives most Universities in Nigeria to adopt cloud, followed by enhanced availability, low environmental impact, reduced IT complexities, mobility, 
scalability, increased operability and reduced investment in physical asset in that order. This result is supported by Behrend, Wiebe, London and Johnson [13] who stated that cloud computing is a technological innovation with a major purpose of reducing IT costs for the college and eliminating many of the time-related constraints for students, making learning tools available and accessible to a larger number of students. EDUCAUSE [14] stressed that cloud computing offers to universities the possibility of concentrating more on teaching and research activities rather than on complex IT configuration and software systems.

Westmont College reports that after deploying six cloudcentric service platforms, it has achieved numerous benefits, including a 65 percent cost reduction up front (over more traditional deployments), and a 55 percent cost saving over the useful lifetime of the solutions. Beyond the cost savings, the college reports a significant increase in user satisfaction, as well as a significant decrease in the amount of IT management time required [8]. Sasikala and Prema [15] emphasized the Cloud Computing trend of replacing software traditionally installed on campus computers (and the computers themselves) with applications delivered via the internet is driven by aims of reducing universities' IT complexity and cost.

TABLE I. BENEFITS OF CLOUD COMPUTING IN NIGERIA UNIVERSITIES $(\mathrm{N}=1742)$

\begin{tabular}{|c|c|c|}
\hline S/N & $\begin{array}{c}\text { Benefits of Cloud } \\
\text { Computing in the } \\
\text { Study Area }\end{array}$ & $\begin{array}{c}\text { \% of } \\
\text { Respondents }\end{array}$ \\
\hline 1 & Enhanced Availability & 99.3 \\
\hline 2 & Reduced Cost & 100 \\
\hline 3 & Scalability & 84.2 \\
\hline 4 & $\begin{array}{c}\text { Low Environmental } \\
\text { Impact }\end{array}$ & 95.6 \\
\hline 5 & End-User Satisfaction & 74.6 \\
\hline 6 & $\begin{array}{c}\text { Mobility } \\
\text { Complexities }\end{array}$ & 85.4 \\
\hline 7 & $\begin{array}{c}\text { Reduced Physical } \\
\text { Asset Investment }\end{array}$ & 83.4 \\
\hline 8 & $\begin{array}{c}\text { Increased } \\
\text { Interoperability }\end{array}$ \\
\hline 9 &
\end{tabular}

Based on the analysis of the findings obtained for the research question 3 in this study as presented in Table 2, a number of challenges currently embattling Universities using cloud services in the study area have been identified. These constraining factors include data insecurity, regulatory compliance concerns, lock-in, privacy concerns, unsolicited advertising and reluctance to eliminate staff positions, reliability challenge and resistance to change in technology in that order. This result is supported by the work of Dan [16] who identified that approximately, 75\% of Chief Information Officer and IT specialists consider security as being the number one risk.
IITE [17] explained that major concern of university administrators and $\mathrm{CIO}$ is around the security of data. Institutions may consider that their data is more secure if it is hosted within the Institution. Transferring data to a third party for hosting in a remote data centre, not under the control of the Institution and the location of which may not be known presents a risk. Another risk identified is that cloud providers target users with unsolicited email or advertising.

Lock-in is also of concern as some companies such as Google and Microsoft allow institutions to co-brand their cloud products. There may be a risk in associating an institution too closely with these companies whose popularity is variable with users [17]. Probably of greater risk is that an institution will become "locked-in" to the products of a particular provider. There are significant costs in migrating from any widely used system. Institutions which start to integrate educational processes with the cloud systems will find it even more difficult to migrate. If a better rival product emerges or the cloud provider decides to impose or increase charges on institutions it may be too late to change.

TABle II. Challenges of Cloud Computing In the Study AREA $(\mathrm{N}=1742)$

\begin{tabular}{|c|c|c|}
\hline S/N & Challenges of using Cloud Computing & $\begin{array}{c}\text { \% of } \\
\text { Respondents }\end{array}$ \\
\hline 1 & Data insecurity & 89.3 \\
\hline 2 & Unsolicited Advertising & 64.6 \\
\hline 3 & Lock-in & 77.6 \\
\hline 4 & Reluctance to eliminate staff positions & 64.6 \\
\hline 5 & Privacy Concerns & 68.9 \\
\hline 6 & Reliability challenge & 64.2 \\
\hline 7 & Regulatory compliance concerns / User \\
& control & 59.0 \\
\hline 8 & Institutional culture / resistance to change & \\
\hline & in technology & \\
\hline
\end{tabular}

\section{CONCLUSION, RECOMMENDATION AND FUTURE WORK}

The poor state of ICT in Nigerian universities has really limited its impact on socio -economic development, quality of graduates and research outputs. Cost has been identified as the major barrier to the survival of ICT in education which can be leveraged through the adoption of cloud computing. Cloud computing can actually help institutions reduce high expenditures on hardware, software and IT maintenance. It can also offer enhanced availability, low environmental impact, reduced IT complexities, mobility, scalability, increased operability and reduced investment in physical asset.

However, the constraining factors to successful adoption and use of cloud computing include data insecurity, regulatory compliance concerns, lock-in, privacy concerns, unsolicited advertising and reluctance to eliminate staff positions, reliability challenge and resistance to change in technology.

Based on the results obtained from this research work, the following recommendations are made. The cloud can help universities to: 
1) Accommodate the rapid increase in mobile device dependency

2) Open their technology infrastructures to businesses and industries for research advancements.

3) Remain updated with the ever-growing resource requirements and energy costs.

4) Store expansive amounts of sensitive data and information that's easily accessible

5) Teach students in new, different ways and help them manage projects and massive workloads with the provisioning of a digital campus storage for class notes, papers and projects.

6) Acquire and implement the latest software and application updates

7) Streamline enrollment and admissions processes that are costly and time-consuming

8) Turn to subscriptions that are scalable and provide options

9) To use applications without installing them on their computers and also allows access to saved files from any computer with an Internet connection.

Future research work can investigate on how the constraining factors to the successful adoption of cloud computing in Nigeria Universities can be managed easily without incurring additional overheads. The readiness assessment of the Universities to the adoption of ICT in various services being offered can also be conducted.

\section{REFERENCES}

[1] B. Neil and Associates, "ICT, Education, Development and the Knowledge Society". GeSCI African Leadership in ICT Program, 2011.

[2] S. Osaat and L. Nsereka, "Impact of Information and Communication Technology on Distance Education: The Case of National Open University of Nigeria", African Research Review, An International Multidisciplinary Journal, Ethiopia Vol. 6 (1), Serial No. 24, January, 2012, Pp. 325-341.

[3] G. B. Iwasokun, B. K. Alese, A. F. Thompson and F. O. Aranuwa, "Statistical evaluation of the impact of ICT on Nigerian universities", International Journal of Education and Development using Information and Communication Technology (IJEDICT), 2012, Vol. 8, Issue 1, pp. 104-120.

[4] M. Gerald and K. Eduan, "Cloud Computing in Higher Education: Implications for South African Public Universities and FET Colleges", Annual Conference on WWW applications, 2012.

[5] Y. G. Abdulsalam and U. Z. Fatima, "Cloud Computing: Solution to ICT in Higher Education in Nigeria", Advances in Applied Science Research, 2011, 2 (6): 364-369, Pelagia Research Library.

[6] F. E. Mehmet and B. K. Serhat, "Cloud Computing for Distributed University Campus", International Conference on the Future of Education, Pixel Publishing International, 2011.

[7] J. Anjali and U.S. Pandey, "Role of Cloud Computing in Higher Education", International Journal of Advanced Research in Computer Science and Software Engineering, Volume 3, Issue 7, 2013,Pg 966-972.

[8] N. Sclater, eLearning in the Cloud, International Journal of Virtual and Personal Learning Environments, Vol 1, No 1, 10-19, IGI Global, 2010.

[9] SO Olabiyisi, TM Fagbola, RS Babatunde. An Exploratory Study of Cloud and Ubiquitous Computing Systems. World Journal of Engineering and Pure and Applied Sciences 2012; 2(5):148-155.
[10] Edtech, "Education in the cloud", Education in the Cloud edtechdigest.com.htm, 2013.

[11] Edudemic, "The Future of Higher Education and Cloud Computing", www.edudemic.com / The Future of Higher Education and Cloud Computing - Edudemic - Edudemic.htm, 2013.

[12] M. Marinela and L. A. Anca, "Using Cloud Computing in Higher Educational: A Strategy to Improve Agility in the Current Financial Crisis". IBIMA Publishing, Vol 20 (2010), Article ID 875547, DOI: $10.5171 / 2011.875547$.

[13] T. S. Behrend, E. N. Wiebe, J. E. London and E. C. Johnson, Cloud Computing Adoption and Usage in Community Colleges. Behaviour \& Information Technology, 30 (2), 2011, 231-240.

[14] EDUCAUSE, "Cloud Computing Explained", http://www.educause.edu/EDUCAUSE+Quarterly/EDUCAUSEQuarterl yMagazineVolum/CloudComputingExplained/206526, 2012.

[15] S. Sasikala \& S. Prema, Massive Centralized Cloud Computing (MCCC) Exploration in Higher Education. Advances in Computational Sciences and Technology, 3 (2), 111-118, 2010.

[16] M. Dan "Cloud Computing in Education", September 12, 2011, [Online]. Available: http://www.cloudave.com/14857/cloud-computingin-education/

[17] IITE, "Cloud Computing in Education", UNESCO Institute for Information Technologies in Education (IITE) Policy Brief, September 2010.

\section{APPENDIX}

Questionnaire for the Evaluation of Impact and Challenges of Cloud Computing Adoption and Use by Universities in Southwestern, Nigeria

The purpose of this questionnaire is to evaluate the impact and challenges of cloud adoption and use by universities in southwestern Nigeria. Your sincere contribution to the research by giving very accurate and honest responses is solicited as confidentiality of volunteered information is guaranteed.

\section{Part I: Biodata of the Respondent}

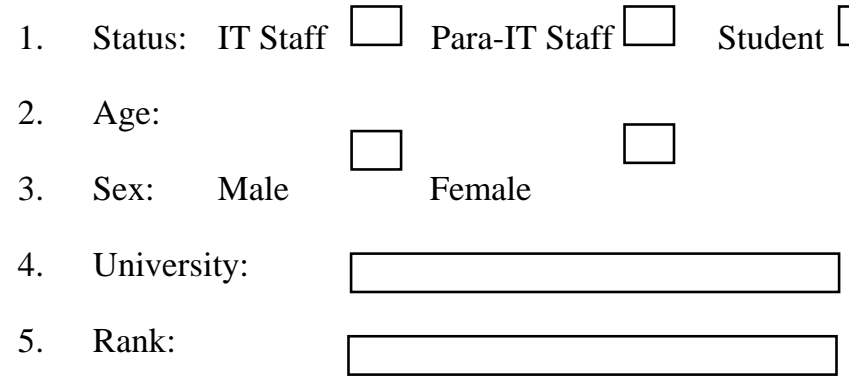

Part II: Assessment of the Trends (Awareness and Adoption) indices of Cloud Computing in Nigerian Universities (To be completed by IT member of Staff)

1. Are you aware of cloud computing in Education?

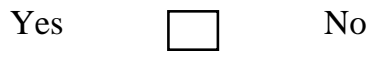

If yes, what cloud services are being adopted and used in your University? Tick as appropriate: 
Infrastructure as a Service (IAAS): for example, storage of educational multimedia resources, hosting of the Elibrary resources, Institutional Learning Management Systems (LMS) like Moodle and Blackboard, Computer laboratories, Telephony, University portal on cloud by cloud providers like Amazon EC2 Elastic Cloud, IBM, Terramark, GoDaddy and Intuit Quick Base among others who presented infrastructure components for rent.

Software as a Service (SAAS): for example, use of ERP, Identity Services, Google Apps which covers the following three main areas: messaging (Gmail, Calendar and Google Talk), collaboration (Google Docs, Video and Sites) and security (email security, encryption and archiving).

Platform as a Service (PAAS): offers Integrated Development Environments (IDE) / platform for rent. For example, use of Google Sites and cloud-based APIs and .NET platforms.

Part III: Assessment of the benefits of Using Cloud Computing in Nigerian Universities. Rate as applicable to your University on the likert scale of Strongly Agree, Agree, Not Sure, Disagree and Strongly Disagree $(\mathrm{N}=1742)$.

\begin{tabular}{|c|c|c|c|c|c|c|}
\hline $\begin{array}{c}\text { Serial } \\
\text { Nos }\end{array}$ & Benefits & $\begin{array}{c}\text { Strongly } \\
\text { Agree }\end{array}$ & Agree & $\begin{array}{l}\text { Not } \\
\text { Sure }\end{array}$ & Disagree & $\begin{array}{l}\text { Strongly } \\
\text { Disagree }\end{array}$ \\
\hline 1 & $\begin{array}{c}\text { Enhanced } \\
\text { Availabilit } \\
y\end{array}$ & 992 & 738 & 09 & 03 & 0 \\
\hline 2 & $\begin{array}{c}\text { Cost } \\
\text { effectivene } \\
\text { ss / } \\
\text { Affordabili } \\
\text { ty }\end{array}$ & 1156 & 586 & 0 & 0 & 0 \\
\hline 3 & $\begin{array}{l}\text { Elasticity / } \\
\text { Scalability }\end{array}$ & 965 & 502 & 260 & 15 & 0 \\
\hline 4 & $\begin{array}{c}\text { Lower } \\
\text { environme } \\
\text { ntal impact }\end{array}$ & 869 & 797 & 67 & 9 & 0 \\
\hline 5 & $\begin{array}{c}\text { End-User } \\
\text { Satisfactio } \\
n\end{array}$ & 967 & 333 & 345 & 97 & 0 \\
\hline 6 & Mobility & 931 & 557 & 189 & 65 & 0 \\
\hline 7 & $\begin{array}{l}\text { Reduction } \\
\text { in IT } \\
\text { Complexiti } \\
\text { es }\end{array}$ & 1005 & 622 & 112 & 03 & 0 \\
\hline 8 & $\begin{array}{c}\text { Less } \\
\text { investment } \\
\text { in physical } \\
\text { assets }\end{array}$ & 1210 & 233 & 215 & 84 & 0 \\
\hline 9 & $\begin{array}{c}\text { Increased } \\
\text { Interopera } \\
\text { bility } \\
\text { between } \\
\text { disjointed } \\
\text { technologi } \\
\text { es }\end{array}$ & 851 & 604 & 202 & 85 & 0 \\
\hline
\end{tabular}


Part IV: Assessment of the challenges of using Cloud Computing: Rate as applicable to your University on the likert scale of Strongly Agree, Agree, Not Sure, Disagree and Strongly Disagree $(\mathrm{N}=1742)$.

\begin{tabular}{|c|c|c|}
\hline Public Universities & $\begin{array}{c}\text { Total Number of } \\
\text { Questionnaires } \\
\text { Returned by } \\
\text { Respondents }\end{array}$ & $\begin{array}{l}\text { Total Not } \\
\text { Returned }\end{array}$ \\
\hline $\begin{array}{l}\text { Ladoke Akintola University of } \\
\text { Technology, Ogbomoso }\end{array}$ & 190 & 10 \\
\hline $\begin{array}{c}\text { Adekunle Ajasin University, } \\
\text { Akungba-Akoko }\end{array}$ & 169 & 31 \\
\hline $\begin{array}{c}\text { University of Ado-Ekiti, Ado- } \\
\text { Ekiti }\end{array}$ & 160 & 40 \\
\hline $\begin{array}{c}\text { University of Agriculture, } \\
\text { Abeokuta }\end{array}$ & 177 & 23 \\
\hline $\begin{array}{c}\text { University of Ibadan, Ibadan, } \\
\text { Oyo State }\end{array}$ & 189 & 11 \\
\hline $\begin{array}{c}\text { Lagos State University, Ojoo, } \\
\text { Lagos State }\end{array}$ & 173 & 27 \\
\hline $\begin{array}{c}\text { Federal University, Oye-Ekiti, } \\
\text { Ekiti State }\end{array}$ & 182 & 18 \\
\hline $\begin{array}{l}\text { Obafemi Awolowo } \\
\text { University, Ile-Ife }\end{array}$ & 172 & 28 \\
\hline $\begin{array}{c}\text { University of Lagos, Lagos } \\
\text { State }\end{array}$ & 168 & 32 \\
\hline $\begin{array}{l}\text { Federal University of } \\
\text { Technology, Akure }\end{array}$ & 162 & 38 \\
\hline
\end{tabular}

\begin{tabular}{|c|c|c|c|c|c|c|}
\hline $\begin{array}{c}\text { Serial } \\
\text { Nos }\end{array}$ & Challenges & $\begin{array}{c}\text { Strongly } \\
\text { Agree }\end{array}$ & Agree & $\begin{array}{l}\text { Not } \\
\text { Sure }\end{array}$ & Disagree & $\begin{array}{l}\text { Strongly } \\
\text { Disagree }\end{array}$ \\
\hline 1 & $\begin{array}{c}\text { Data } \\
\text { insecurity }\end{array}$ & 728 & 828 & 108 & 78 & 0 \\
\hline 2 & $\begin{array}{l}\text { Unsolicited } \\
\text { Advertising }\end{array}$ & 612 & 513 & 511 & 106 & 0 \\
\hline 3 & Lock-in & 543 & 809 & 289 & 101 & 0 \\
\hline 4 & $\begin{array}{l}\text { Reluctance } \\
\text { to eliminate } \\
\text { staff } \\
\text { positions }\end{array}$ & 690 & 434 & 467 & 151 & 0 \\
\hline 5 & $\begin{array}{c}\text { Privacy } \\
\text { Concerns }\end{array}$ & 606 & 596 & 385 & 155 & 0 \\
\hline 6 & $\begin{array}{l}\text { Reliability } \\
\text { challenge }\end{array}$ & 389 & 729 & 420 & 204 & 0 \\
\hline 7 & $\begin{array}{c}\text { Regulatory } \\
\text { compliance } \\
\text { concerns / } \\
\text { User } \\
\text { control }\end{array}$ & 765 & 752 & 244 & 104 & 0 \\
\hline 8 & $\begin{array}{l}\text { Institutional } \\
\text { culture / } \\
\text { resistance } \\
\text { to change } \\
\text { in } \\
\text { technology }\end{array}$ & 432 & 599 & 480 & 231 & 0 \\
\hline
\end{tabular}

Table Showing the Summary of the Public Universities in the Southwestern Part of Nigeria 